\title{
Multiple Shaker Potassium Channels in a Primitive Metazoan
}

\author{
Timothy Jegla, ${ }^{1}$ Nikita Grigoriev, ${ }^{2}$ Warren J. Gallin,, ${ }^{2}$ Lawrence Salkoff, ${ }^{1}$ and Andrew N. Spencer ${ }^{2}$ \\ ${ }^{1}$ Department of Anatomy and Neurobiology, Washington University School of Medicine, St. Louis, Missouri 63110 \\ and ${ }^{2}$ Department of Biological Sciences, University of Alberta, Edmonton, Alberta, Canada T6G 2E9 and Bamfield \\ Marine Station, Bamfield, British Columbia Canada VOR 1B0
}

\begin{abstract}
Voltage-gated potassium channels are critical elements in providing functional diversity in nervous systems. The diversity of voltage-gated $\mathrm{K}^{+}$channels in modern triploblastic metazoans (such as mollusks, arthropods and vertebrates) is provided primarily by four gene subfamilies (Shaker, Shal, Shab, and Shaw), but there has been no data from the ancient diploblastic metazoans until now. Diploblasts, represented by jellyfish and other coelenterates, arose during the first major metazoan radiation and are the most structurally primitive animals to have true nervous systems. By comparing the $\mathrm{K}^{+}$channels of diploblasts and triploblasts, we may determine the fundamental set of $\mathrm{K}^{+}$ channels present in the first nervous systems. We now report the isolation of two Shaker subfamily cDNA clones, jShak1 and jShak2, from the hydrozoan jellyfish Polyorchis penicillatus (Phylum Cnidaria). JShak1 and jShak2 express transient outward currents in Xenopus oocytes most similar to Shaker currents from Drosophila in their rates of inactivation and recovery from inactivation. The finding of multiple Shaker subfamily genes is significant in that multiple Shaker genes also exist in mammals. In Drosophila, multiple Shaker channels are also produced, but by a mechanism of alternative splicing. Thus, the Shaker $\mathrm{K}^{+}$ channel subfamily had an established functional identity prior to the first major radiation of metazoans, and multiple forms of Shaker channels have been independently selected for in a wide range of metazoans.
\end{abstract}

[Key words: Shaker, potassium channel, voltage-gated, jellyfish, Cnidarian, diploblast, triploblast, polyorchis, inactivation]

Electrical excitability is a fundamental property of the neuromuscular systems of metazoans. This property is conferred by a diverse set of voltage-gated $(\mathrm{Vg})$ ion channel proteins that has evolved in concert with neurons and other excitable cells. Neurobiologists have come to appreciate that the surprisingly varied responses of neurons to electrical excitation can in a large part

\footnotetext{
Received June 14, 1995; revised Aug. 3, 1995; accepted Aug. 7, 1995.

We thank Dr. Aguan Wei for his role in developing our PCR screen, as well as his helpful comments and enthusiasm. The Shaker H37 clone was kindly provided by Dr. Mark Tanouye, Shaker $B$ by Dr. Tom Schwarz, and $K v 1.2$ by Dr. David McKinnon. We thank the Bamfield Marine Station for their assistance in collecting and holding jellyfish and maintenance of a Xenopus colony. Research was supported hy grants from the NIH and MDA to I awrence Salkoff and from the NSERC to W.J.G. and A.N.S.

Correspondence should be addressed to Timothy J. Jegla, Washington University School of Medicine, Department of Anatomy and Neurobiology, Box 8108,660 South Euclid Avenue, St. Louis, MO 63110.

Copyright (C) 1995 Society for Neuroscience $\quad 0270-6474 / 95 / 157989-11 \$ 05.00 / 0$
}

be accounted for by a diverse, but highly conserved, set of $\mathrm{Vg}$ potassium channel proteins that are present in most metazoans (Rudy, 1988; Salkoff et al., 1992).

The molecular basis of $\mathrm{K}^{+}$channel diversity is well understood in many triploblastic metazoans, including vertebrates (Jan and Jan, 1990; Rudy et al., 1991; Salkoff et al., 1992; Chandy and Gutman, in press), arthropods (Jan and Jan, 1990; Salkoff et al., 1992; Pongs, 1993), and mollusks (Pfaffinger et al., 1991; Quattrocki et al., 1994; Zhao et al., 1994), and has been examined in other triploblasts groups such as annelids (Johansen et al., 1990), nematodes (Wei et al., 1991), and flatworms (Kim et al., 1995). In these organisms, much of the $\mathrm{K}^{+}$channel diversity appears to be encoded by four closely related gene subfamilies of $\mathrm{Vg} \mathrm{K}^{+}$channels: Shaker, Shal, Shab, and Shaw. However, it has not been clear whether this set of $\mathrm{Vg} \mathrm{K}^{+}$channels diversified within the triploblastic lineage or whether it was, at least in part, present during the establishment of the nervous system in more primitive metazoans.

The most ancient extant metazoans to have true nervous systems are the diploblasts, organisms such as jellyfish, sea anemones, and comb-jellies. These organisms have only two germinal layers, lacking a true mesoderm. Both the fossil record and molecular phylogenies based on ribosomal RNA sequences place the emergence and diversification of the extant diploblastic phyla well before the appearance of modern triploblasts, during an initial major radiation of metazoan species (Christen et al., 1991; Morris, 1993; Wainwright et al., 1993). Thus, the first nervous systems most likely appeared in one of the latest common ancestors of diploblasts and triploblasts.

Physiological evidence shows that the diploblasts, like triploblasts, have a diverse set of $\mathrm{Vg} \mathrm{K}$ currents (Anderson and McKay, 1987; Dunlap et al., 1987; Holman and Anderson, 1991; Meech and Mackie, 1993; Przysiezniak and Spencer, 1994), hinting at an early diversification of $\mathrm{Vg} \mathrm{K}^{+}$channel genes. By examining the molecular diversity of $\mathrm{Vg} \mathrm{K}^{+}$channels in diploblasts such as jellyfish, we can gain an understanding of the molecular diversity of $\mathrm{Vg} \mathrm{K}^{+}$channels in the first nervous systems and how it has been conserved or specialized to meet the needs of modern triploblasts with their complex nervous and effector systems.

Using a PCR screening protocol, based on degenerate primers corresponding to the regions most highly conserved between the Shaker, Shal, Shab, and Shaw subfamilies, we have isolated two Shaker subfamily homologs, $j S h a k 1$ and $j S h a k 2$, from the hydromedusan jellyfish Polyorchis penicillatus. We report the sequences of these $\mathrm{K}^{+}$channel subunits and demonstrate remarkable similarity to their triploblastic homologs. These results show that the Shaker $\mathrm{Vg} \mathrm{K}^{+}$channel gene subfamily has been 
functionally differentiated from other $\mathrm{Vg} \mathrm{K}^{+}$channel lineages at least since the appearance of the nervous system. Thus, the diversity of $\mathrm{Vg} \mathrm{K} \mathrm{K}^{+}$channels observed in triploblasts is likely to have arisen during or even prior to the earliest major radiation of metazoan species.

\section{Materials and Methods}

Cloning of $\mathrm{jShak} 1$ and jShak2. Amplification and isolation of fragments of jShakl and jShak2 from Polyorchis penicillatus genomic DNA was performed as described in Jegla and Salkoff, 1995. Briefly, the degenerate primers used to generate the fragments were 5'-TCGGAATT-



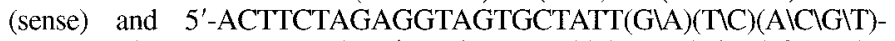
$A G\left(A \mid C \backslash G Y^{\prime} I^{\prime}\right) A C\left(A \mid C \backslash G \backslash I^{\prime}\right) C\left(C^{\prime}-3\right.$ ' (antisense) which are derived from the consensus amino acid sequences of the pore region [MTTVGYG(D/E)] and sixth transmembrane domain [GVL(T/V)TIAL] of $\mathrm{Vg} \mathrm{K}^{+}$channels. The $j S h a k l$ and $j S h a k 2$ fragments obtained in the amplification screen were used to probe oligonucleotide dT primed Polyorchis cDNA libraries under high stringency conditions (Butler et al., 1989). Purification of mRNA from neuronally enriched $P$. penicillatus tissue samples and construction of the cDNA libraries in the lambdaZAP II vector (Stratagene, La Jolla) have been described previously (Gallin, 1991). Bluescript $\mathrm{SK}^{-}$subclones of each positive clone were obtained using Stratagene's in vivo excision protocol and sequenced in both directions. This procedure yielded a complete cDNA clone of jShakl. However, all jShak 2 cDNAs were truncated, containing only a region encoding $\mathrm{S} 1$ through the $3^{\prime}$ end of the coding sequence. The missing $5^{\prime}$ region was obtained by high stringency amplification $\left(95^{\circ} \mathrm{C} 1 \mathrm{~min}, 60^{\circ} \mathrm{C} 3 \mathrm{~min}\right.$ 30 cycles) of a cDNA bank with $0.5 \mathrm{pmol} / \mu \mathrm{l}$ of an oligonucleotide matching the T7 region of Bluescript 5'-\{GCGCGTAATACGACTCACTATAGGG) $-3^{\prime}$ and $25 \mathrm{pmol} / \mu \mathrm{l}$ of an antisense oligonucleotide matching the $3^{\prime}$ end of the jShak 2 coding sequence $5^{\prime}$-(ACACTCTAGATAAGTGGTCACGTGATTTAACTCG)- $3^{\prime}$. A second round used 5 $\mathrm{pmol} / \mu \mathrm{l}$ of the T7 oligonucleotide and $25 \mathrm{pmol} / \mu \mathrm{l}$ of a nested antisense oligonucleotide near the pore region of jShak2 $5^{\prime}$-(TCCGGTCGACGTAGAGGGGAATAAATCGCCATA)-3'. The product was cut with Xho $I$ and Nhe I and subcloned into the Xho I and Xba I sites in Bluescript II $\mathrm{KS}^{+}$(Stratagene, La Jolla). Three separate clones were sequenced in both directions to minimize the possibility of reporting PCR-introduced mutations.

Genomic structures were determined by high stringency PCR amplification of genomic DNA with several oligonucleotides flanking the coding regions of $j S h a k l$ and $j S h a k 2$ and oligonucleotides internal to the coding sequence. In all cases, single bands were amplified. In instances where the product resulting from amplification of genomic DNA corresponded in size to a band amplified from the cDNA clone with the identical oligonucleotides, genomic restriction mapping was used to verify the identity of genomic product. In cases for which the size of the genomic band exceeded that of the cDNA, the genomic band was subcloned into the Sma I site of Bluescript II SK ${ }^{+}$and sequenced to confirm the existence and position of the intron.

Alignments and phylogenetic trees. The alignments used to produce the pairwise identity data were generated in Microgenie (Beckman, Palo Alto) and adjusted by eye. Alignments which were used to produce maximum parsimony trees based on the jShak1, jShak2 and 9 triploblastic $\mathrm{Vg} \mathrm{K}{ }^{+}$channels representing the Shaker, Shal, Shab, and Shaw gene subfamilies were generated using the SEQSEE suite of programs (Wishart et al., 1994). Only sections of the Tl region and membrane spanning core (S1-S6) that have conserved lengths between the Shaker, Shal, Shab, and Shaw subfamilies were used for tree building. Trees were constructed by maximum parsimony, as implemented in the PAUP computer program (Swofford, 1993). Tree lengths were calculated using a step matrix that weighted changes between amino acids according to the minimum number of nucleotide changes that were necessary to achieve the change in amino acids. A heuristic search for trees was performed, using random addition to generate initial trees, tree bisection and reconnection for branch swapping. The consensus maximum parsimony tree shown in Figure 2 was constructed from the shortest 13 trees found in this search.

Construction of Xenopus oocyte expression vectors. The jShak1 expression vector was generated by PCR amplification of a previously constructed $j$ Shakl-Bluescript II $\mathrm{KS}^{+}$subclone with two primers: a sense primer 5'-(GGGAGCTCGAGCCACCATGATGTTTGTAGCCACT) $-3^{\prime}$ that replaces the $5^{\prime}$ UT sequence with a consensus translation initiation sequence (Kozak, 1987) and an internal primer $3^{\prime}$ of a unique internal Sac I site 5'-(AATCATAATCATTCATCG)-3'. The PCR product was then digested with Sac I and cloned into the jShak1-Bluescript $\mathrm{KS}^{+}$subclone digested with Sac I. The PCR amplified region was sequenced in both directions to confirm correct orientation and lack of PCR-introduced mutations. A truncated jShakl construct ( $j S h a k 1 T$ ) that eliminates the first 23 predicted amino acids and replaces phenlyalanine 24 with an initiator methionine preceded by a consensus translational initiation sequence was constructed using the sense primer $5^{\prime}$-(GGGAGCTCCACCATGGAAGACAATGCAGA)-3'.

The $j$ Shak 2 construct was produced in two steps. First, an incomplete jShak 2 cDNA isolated in the original bank screen described above was cut with Nhe $I$ and Not $I$ and subcloned into an Spe $1 /$ Not $I$ cut pBScMXT oocyte expression vector (Wei et al., 1994). The $5^{\prime}$ end was amplified with a sense oligonucleotide 5'-(TTACGAATTCCACCATGTTACCAGTTCTAACGCAAACG)-3' which replaces the 5' UT sequences with a consensus translation initiation sequence and the previously described pore region antisense oligonuclentide. This product was cut with Eco RI and Nhe I and subcloned into the vector produced in the first step (Eco RI/Nhe I cut). The amplified region was sequenced in both directions to confirm that no PCR-introduced mutations existed.

Expression of cRNA in Xenopus oocytes. Capped cRNAs were prepared by run-off transcription with either T7 RNA polymerase (for $j$ Shakl and jShaklT), or with T3 RNA polymerase (jShak2, Shaker H37, Shaker $B$, and $K v 1.2$ ) using the mMessage mMachine kit (Ambion, Austin). Mature stage IV Xenopus oocytes were prepared for injection as described in Wei et al., 1990. Oocytes were injected with $50 \mathrm{nl}$ of cRNA at concentrations of 5-100 ng/ $\mu$ l (adjusted based on the expression level of the particular construct), and incubated at $15^{\circ} \mathrm{C}$ for $1-3 \mathrm{~d}$ in ND96 $\left(96 \mathrm{mM} \mathrm{NaCl}, 2 \mathrm{mM} \mathrm{KCl}, 1.8 \mathrm{mM} \mathrm{CaCl}_{2}, 1 \mathrm{~mm} \mathrm{MgCl}, 5 \mathrm{~mm}\right.$ HEPES-NaOH, pH 7.5) supplemented with $100 \mathrm{U} / \mathrm{ml}$ penicillin, 100 $\mu \mathrm{g} / \mathrm{ml}$ streptomycin and $2.5 \mathrm{~mm}$ sodium pyruvate.

Electrophysiology. Recording methods used were as previously published in Covarrubias et al., 1991. Briefly, whole cell recordings were made $13 \mathrm{~d}$ after injection at $22^{\circ} \mathrm{C}$ by conventional two microelectrode voltage-clamp techniques. Electrodes ranged from $0.3-0.8 \mathrm{M} \Omega$ resistance and were filled with $3 \mathrm{~m} \mathrm{KCl}$. The standard recording solution consisted of ND96 with $1 \mathrm{~mm} 4,4^{\prime}$-diisothiocyanatostilbene-2,2' disulfonic acid (DIDS) to block native oocyte chloride currents. Tetraethylammonium (TEA) and 4-aminopyridine (4-AP) were dissolved in this standard solution at the given concentrations. Currents were digitally acquired with CCURRENT using linear leak subtraction, filtered at $1 \mathrm{kHz}$ with an 8-pole Bessel filter and analyzed with CQUANT (Baker and Salkoff, 1990).

\section{Results}

\section{Cloning of jShak1 and jShak2}

We designed a PCR-based method to screen for jellyfish $\mathrm{Vg} \mathrm{K} \mathrm{K}^{+}$ channel homologs that relied only on short stretches of conservation and compensated for differences in codon bias by using degenerate primers. We chose one degenerate primer to match the amino acid sequence of the $\mathrm{K}^{+}$-selective pore region (Hartmann et al., 1991; Yellen et al., 1991; Yool and Schwarz, 1991) which is highly conserved in all the $\mathrm{Vg} \mathrm{K}^{+}$channels (MTTVGYGD) as well as most other $\mathrm{K}^{+}$channels. The antisense primer matched a stretch of S6 (GVL(T/V)IAL), the most highly conserved membrane-spanning domain, which is invariant in Shaker, Shal, Shab, and Shaw (Wei et al., 1990). We used the same low stringency amplification protocols described in Jegla and Salkotf (1995) in which novel Paramecium $\mathrm{K}^{+}$channel clones were isolated starting with these primers. Using this screen, fragments of two jellyfish $\mathrm{Vg} \mathrm{K}{ }^{+}$channcls, jShak1 and jShak2, were isolated from Polyorchis penicillatus genomic DNA. These fragments were then used as a probe to isolate complete clones of jShak1 and jShak2 from a Polyorchis penicillatus cDNA library, as described in the Materials and Methods section.

\section{Conservation with triploblastic Shaker channels}

An alignment of the deduced anino acid sequences of jShak1 and jShak2 to triploblastic Shaker homologs from Drosophila 
Table 1. Percent conservation of amino acids between the jellyfish $\mathrm{Vg}^{+}$channels $j$ ShakI and jShak1 and triploblastic $\mathrm{Vg} \mathrm{K} \mathrm{K}^{+}$channels

\begin{tabular}{llllllll} 
& jShakl & jShak2 & Shaker B & Mus Kv1.2 & Shal & Shab & Shaw \\
\hline jShakl & & $50(55)$ & $48(51)$ & $49(52)$ & $45(41)$ & $44(34)$ & $42(37)$ \\
jShak2 & $50(55)$ & & $52(51)$ & $51(53)$ & $44(44)$ & $46(29)$ & $46(35)$ \\
Shaker B & $48(51)$ & $52(51)$ & & $69(88)$ & $42(48)$ & $43(33)$ & $44(41)$ \\
\hline
\end{tabular}

Percentage amino acid identities are shown for pairwise alignments between jShakl, jShak2, the Drosophila Shaker $B$ (Timpe et al., 1988a), Shal, Shab, and Shaw (Butler et al., 1989) Vg K+ channels and the Mus Shaker homolog Kv1.2 (McKinnon, 1989). Identities are measured from the first residue of $S 1$ to the last residue of $S 6$, and for the most highly conserved section of the $\mathrm{Tl}$ domain (shown in parentheses) corresponding to amino acids 47 through 126 in $j$ Shakl.

and Mus is shown in Figure 1. Extensive conservation between jShak1, jShak2, and triploblastic Shaker homologs extends from the T1 tetramerization domain (Li et al., 1992; Shen et al., 1993; Hopkins et al., 1994) in the N-terminal through the entire membrane-spanning core of the channels, which includes six transmembrane domains (S1-S6) and a $\mathrm{K}^{+}$-selective pore motif. Note that conservation is particularly high in the pore and S6 regions to which our degenerate primers were made. Even the N-terminal "inactivation ball" region (Hoshi et al., 1990; Zagotta et al., 1990) shows limited sequence conservation. However, there is little conservation between jShak1, jShak2, and triploblastic Shaker homologs in the proximal N-terminal and distal C-terminal regions (which show little conservation even among triploblastic Shaker homologs).

In pairwise comparisons of the conserved core region (SI through S6), jShakl and jShak2 share approximately $50 \%$ amino acid identity to each other and to triploblastic Shaker homologs. This is less than the approximately $70 \%$ identity shared among triploblastic Shaker homologs (Salkoff et al., 1992; Jegla and Salkoff, 1994), but is higher than the approximately $40 \%$ level of identity conserved among jShakl and jShak2 and the other voltage-gated $\mathrm{K}^{+}$channel subfamilies, Shab, Shal, and Shaw. This higher identity to Shaker versus Shal, Shab, or Shaw is even more pronounced in the T1 domain, and suggests that $j$ Shak 1 and $j$ Shak 2 are specifically Shaker homologs. A summary of these pairwise comparisons is provided in Table 1.

We constructed phylogenetic trees including jShakl, jShak2 and 9 triploblastic $\mathrm{Vg} \mathrm{K}^{+}$channel sequences from the Shaker; Shal, Shab, and Shaw subfamilies to confirm the inclusion of jShakl and jShak2 within the Shaker subfamily, using the maximum parsimony computer program PAUP of Swofford (1993). A maximum parsimony consensus tree built from the 13 shortest (best) trees found by this progran is shown in Figure 2. All 13 trees place $j$ Shakl and $j S h a k 2$ in the Shaker subfamily. In all trees, the two jellyfish Shaker channels diverge from the triploblastic Shaker homologs at an earlier time than the divergence of the triploblastic Shakers from each other, consistent with the early divergence of the diploblastic and triploblastic lineages. The consensus tree is consistent with the previous findings of Strong et al. (1993) in grouping the Shaker and Shal subfamilies. Less certain is whether the Shaw subfamily groups with the Shab subfamily $(77 \%)$, as found by Strong et al. (1993), or the Shal subfamily $(23 \%)$.

\section{Multiple Shaker genes and genomic organization}

As in vertebrates, Shaker is a multigene subfamily in Polyorchis. Gene duplication has produced a large set of Shaker genes with intronless coding regions in mammals (Chandy et al., 1990;
Douglass et al., 1990; Swanson ct al., 1990; Chandy and Gutman, in press), so we were interested to see if introns were present in Polyorchis. We examined the genomic structure of the jShakl and jShak 2 coding regions by PCR amplification of $P o$ lyorchis genomic DNA as described in the Materials and Methods. The coding region of jShakl appears to be intronless because no length differences are seen between the cDNA and genomic fragments encompassing the entire coding region. However, the $j S h a k 2$ coding region contains a single intron of approximately $1.2 \mathrm{~kb}$ in length in the region encoding the C-terminal cytoplasmic domain (Fig. 1, arrow).

\section{Functional properties}

Expression of cRNAs from jShakl and jShak2 in Xenopus oocytes provides further evidence that $j S h a k l$ and $j S h a k 2$ belong to the Shaker subfamily. Both $j S h a k 1$ and $j S h a k 2$ produced currents that resemble triploblastic invertcbratc Shaker currents with respect to rapid activation and inactivation. Figure 3 shows a comparison of families of outward currents recorded from oocytes injected with jShak1, jShak2, and two Drosophila splice variants, Shaker B (Timpe et al., 1988a) and Shaker H37 (Kamb et al., 1988). The biophysical and pharmacological properties of these currents are summarized in Table 2.

Although the $j S h a k l$ and $j S h a k 2$ currents differ substantially in their rates of inactivation (Fig. $4 A$ ), both fall within the range of inactivation rates observed for different splice variants of Drosophila Shaker (Fig. $4 B$ ). Plots of the major time constant of inactivation (Tau) versus voltage are shown in Figure $4 C$. JShakl is most similar to the rapidly inactivating Drosophila Shaker splice variants (e.g., Shaker B), whereas jShak2 has an inactivation rate similar to the more slowly inactivating Shaker currents such as Shaker H37 and Aplysia Shaker (Pfaffinger et al., 1991). For these slower inactivating types, the inactivation time constant is greater than $20 \mathrm{msec}$ at $+60 \mathrm{mV}$. JShak $l$ is also similar to Drosophila Shaker $B$ in having a small sustained current component that does not inactivate over short voltage steps (Fig. 4A) (Timpe et al., 1988a,b; Isacoff et al., 1990). In contrast, JShak2 inactivates completely during shorter steps, similar to Shakers $A$ and $C$ (Timpe et al., 1988a,b; Isacoff et al., 1990).

Because there is no significant conservation among the N-terminal regions of most triploblastic Shaker channels, we were surprised to observe substantial conservation between the N-terminal of $j$ Shakl and the Drosophila Shaker B channel (Fig. 5A). The fast component of inactivation in Shaker $B$ occurs by an N-terminal "ball and chain" mechanism (Hoshi et al., 1990; Zagotta et al., 1990); when this region is removed, rapid inactivation of the current is lost. To test the functional significance 


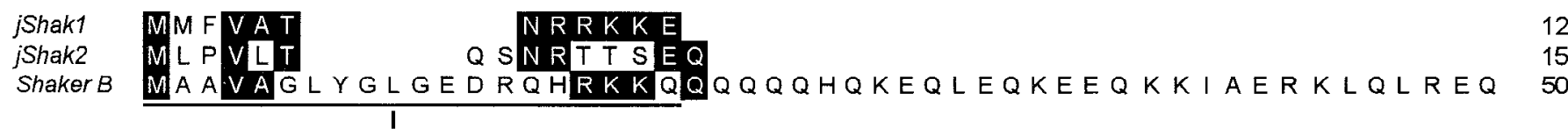

jShak1 GENKDDEMKAG FEDNADIANDEEQGYNSADQ 43 jShak2 SLYNTKTNNK SSPFRNGE PVCNPVSSPVKNPNIDD NNNKK 55 Shaker $B$ QLQRNSLDGYGSLPKLSSQ DEEGGAGHGFGGGPQHFEPIPHDHDFCER 98 KV1.1 $M T V M S G E N A D E A S T A P G H P Q D G S Y P R Q A D H D D H E C C E R$

jShak 1 jShak2 Shaker B Kv1.1



I VGGKRFQTTYNKT

ERFPLSLLGDTERRNQFYNPNTGELFFDRHRP 38

jShak1

jShak2

Shaker B

Kv1.1

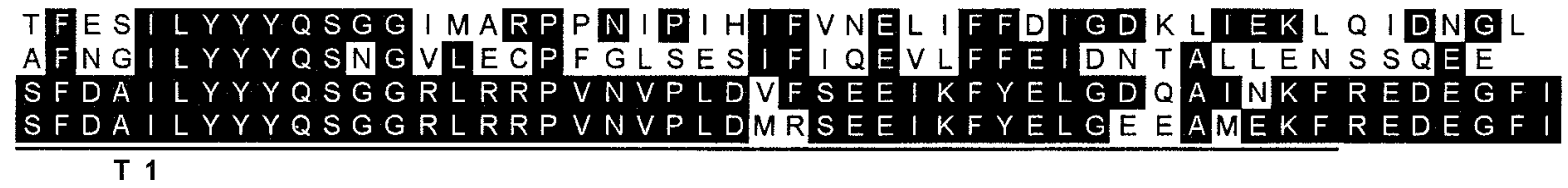

jShak1

jShak2

Shaker B

KV1.1

KELQVVEDLPNYEPFKALWQFLENPDSSNAAKIFAILLSVVIIVVSLIMFV NENSHELLPSNPYLCKIWVLFEQPSSSIYAKIVA I I SVLVILISIVVFC KEEE RPLPDNEKQRKVWLLFEYPESSQAARVVAIISVFVILLSIVIFC KEEE RPLPEKEYQRQVWLLFEYPESSGPARVIALVSVMVILISIVIF C

jShak1

jShak2

Shaker B

KV1.1

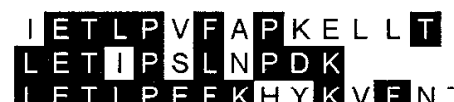

LETIPSLNPDK

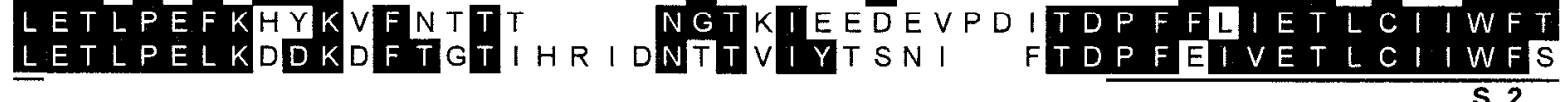

NNGT I YKTVYSEHATWMFTVNTAVICWFT

PEGSHMR VT

WFI I N T I CNSWFT

jShak1

jShak2

Shaker B

Kv1.1

jShak1

jShak2

Shaker B

Kv1.1

jShak1

jShak2

Shaker B

Kv1.1

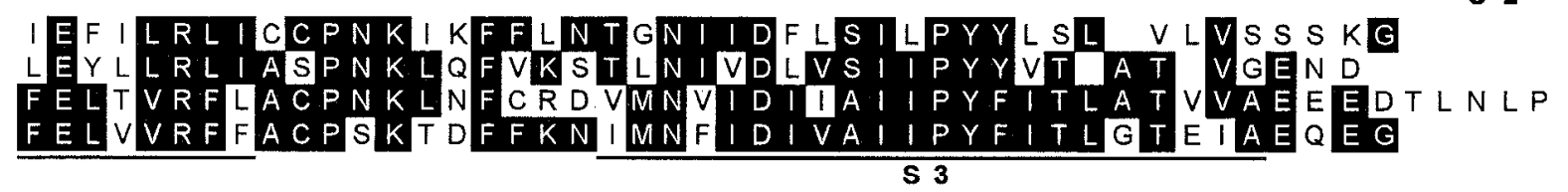

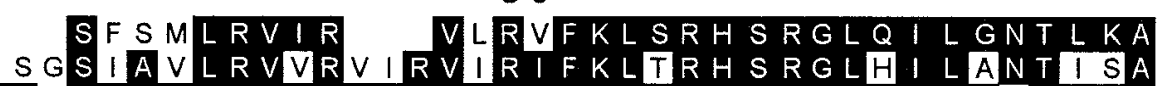

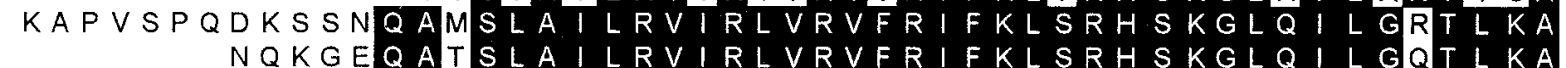
NQKGEQATSLA ILRVIRLVRVFR IFKLSRHSKGLQ I L GQTLKA SF NELMMLAFFLFVMILIFGSCVYYAEYQEPGTKFISIPSSFWWAIVTMT SLHELCMLVLFLA I GVVLFSSAAYYAESANSQTGFKS I PHGFWWAVVTMT SMRELGLLIFFLFIGVVLFSSAVYFAEAGSENSFFKS IPDAFWWAVVTMT. SMRELGLLIFFLFIGVILFSSAVYFAEAEEAESHFSS IPDAFWWAVVSMT

jShak1 TVGYGDMHPVTFWGQ IVGSMAVVCGVLTIALPVPVVVSNFEYFYTKERNR jShak2

Shaker B Kv1.1

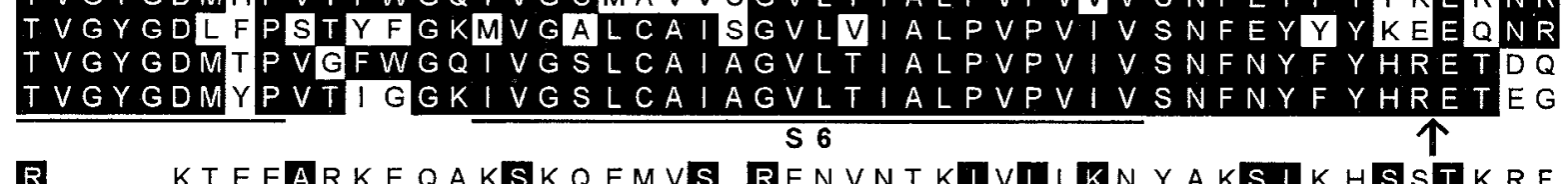
R KTEEARKEQAKSKQEMVS RENVNTKTVLLKN YAKSIKHSSTKRF RQREHELQKKELLDGQLNPIRDSIRMMTEASIILAGGTDNEEGDRQTPDN E EMQ SQNFNHVTSCPYLP GTLGQ HMKKSSLSESSSDMMDL E E Q AQLL HVSSPNLAS DS D LSRRSSITISKSEYMEI

jShakt

Shaker B

Kv1.1

jShak1

jShak2

Shaker B

SRNRREGKTQYSPNMSLNLKDRRQTARV

L I L

NINAMLKTQNKYQNQFTFLIKSTQDDEMADYVNLCHVVKMTIKTKNTS

DDGVESTPGLTETHPGRSAVAPFLGAQQQQQQQPVASSLSMSIDKQLQHP EEDMNNSI AHYRQAN IRT GNCTTADQNCVNKSKLLT DV

ShakerB LQHVTQTQLYQQQQQQQQQQQNGFKQQQQQTQQQLQQQQSHTINASAAA

Shaker B SGSGSGLTMRHNNALAVSIETDV

Figure 1. Alignment of the deduced amino acid sequences of the jShak1, jShak2, Drosophila Shaker B (Timpe et al., 1988a) and the mouse Shaker homolog Kv1.1 (Tempel et al., 1988). Identical amino acids are shown in reversed lettering (white on black). Membrane-spanning domains are underlined and labeled S1 through S6. Also underlined are the putative pore-forming region (Pore), the N-terminal inactivation ball of Shaker

279

275

341

311 312 391 321

361 362 441 371 411 412 491 421 456 462 531 457 487 510 581 495 631 655 
of the conservation between jShakl and Shaker B. we removed the first 23 amino acids of $j S h a k l$ and expressed the truncated construct ( $j$ Shak1T). As with Shaker B, the truncation completely removed rapid inactivation (Fig. $5 B, C$ ) from the $j S h a k l$ current. This result demonstrates the conservation of the $\mathrm{N}$-terminal inactivation ball mechanism. Partial inactivation of the jShaklT current occurs during prolonged $(3 \mathrm{sec}$ ) depolarizations, suggesting the presence of a second, possibly C-type, inactivation process (data not shown).

JShak1 and jShak2 differ substantially in their rates of recovery from inactivation, with $j S h a k l$ showing more rapid recovery (Fig. 6A). Both have two distinct time components to their recovery from inactivation (Table 2, Fig. $6 B, C$ ). Two separable components to recovery could suggest recovery from two inactivated states. The fast component of recovery for $j$ Shakl (Tau $=24.4 \mathrm{msec}$ at $-100 \mathrm{mV}$ ) is very similar to the rapid recovery of the Shaker $B$ splice variant (Tau $=42.6 \mathrm{msec}$ at $-100 \mathrm{mV}$ ), which has mainly N-type inactivation. The slow component is similar to the recovery rate of the Shaker $H 37$ splice variant and could conceivably reflect recovery from C-type inactivation (Fig. 6D). Both Drosophila Shaker currents recover with a single exponential time course. The extremely slow recovery of the $j$ Shak2 current is similar to the Drosophila Shaker $A$ and $C$ splice variants (Timpe et al., 1988h) and Aplysia Shaker (Pfaffinger et al., 1991).

One difference between the jellyfish Shaker currents and their triploblastic counterparts is that $j S h a k 1$ and $j S h a k 2$ both operate in a more positive voltage range. JShak1 and jShak2 have conductance versus voltage $(\mathrm{gV})$ relations and steady state inactivation (ssi) relations that show a depolarized shift with respect to those of typical triploblastic Shaker homologs (Fig. 7). The magnitude of this shift relative to oocyte-expressed Shaker currents in other species is approximately $+25 \mathrm{mV}$ for the ssi curves and almost $+40 \mathrm{mV}$ for the $\mathrm{gV}$ curves. Drosophila Shaker currents, however, can exhibit equally large shifts in their voltage operating range within some cell types (Hevers and Hardie, 1995).

An additional obscrvation of interest is that the apparent voltage sensitivity differs substantially between the jellyfish and triploblastic Shakers. Both jShakl and jShak2 show a lower voltage sensitivity when compared to triploblastic Shaker homologs by three measures: a reduced slope of the $\mathrm{gV}$ curve, a reduced limiting slope (which presumably provides a lower limit estimate on the number of equivalent gating charges $(z)$ required to open the channel (Almers, 1978; Armstrung, 1981; Logothetis et al., 1992), and a reduced slope of the ssi curve (which may reflect the steepness of the voltage dependence of activation; Papazian et al., 1991); see Figure 7 and Table 2. Each of these measures suggests a reduction of voltage dependence of approximately $30 \%$. These differences apparently do not reflect a difference in the number of gating charges in the $\mathrm{S} 4$ region. All higher metazoan Shakers as well as jShak2 have seven positive charges in the $\mathrm{S} 4$ region. JShakJ, on the other hand, has only six $\mathrm{S} 4$ charges (Fig. 1).

JShakl and jShak2 have pharmacological properties typical of Shaker currents. Both are similarly sensitive to block by 4-aminopyridine (having an $\mathrm{IC}_{50}$ of $0.5 \mathrm{~mm}$ or less), but differ 20 -fold

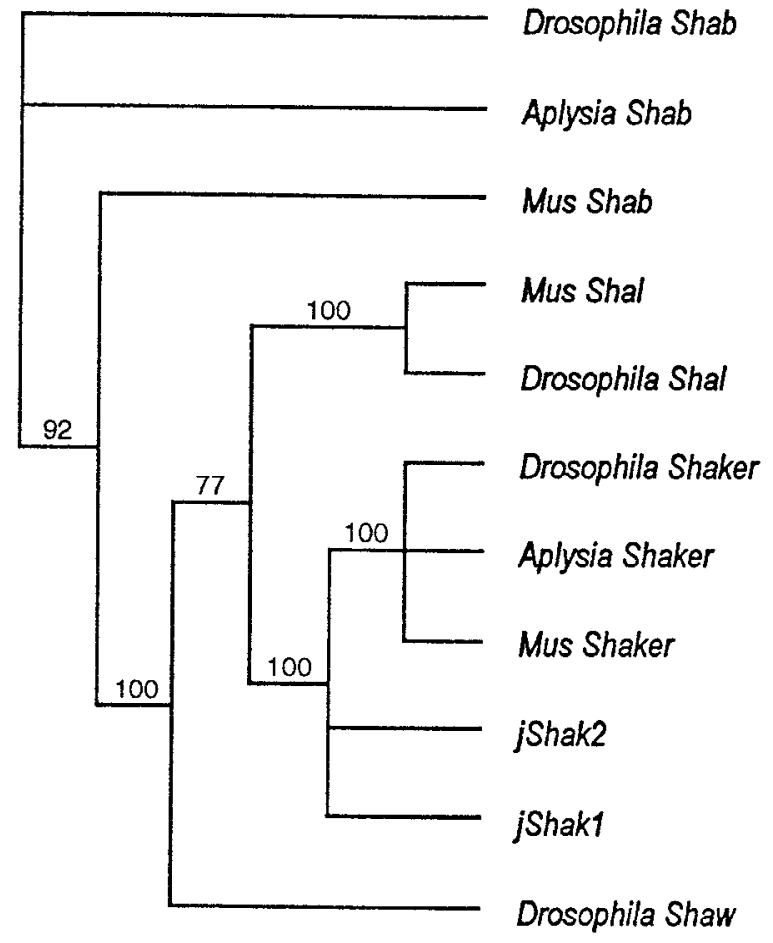

Figure 2. Consensus maximum parsimony tree derived from jShakl, jShak2, and nine triploblastic Vg K ${ }^{+}$channels representing the Shaker, Shal, Shab, and Shaw gene subfamilies. Numbers represent the percentage of occurrences of a particular branch point in the individual maximum parsimony trees used to construct this consensus tree. The references and accession numbers for the sequences used are as follows: Drosophila Shaker (Papazian et al., 1987; M17211) Drosophila Shal, Drosophila Shab, and Drosophila Shaw (Butler et al., 1989; M32660, M32659, M32661, respectively); Mus Shaker (Tempel et al., 1988; Y00305), Mus Shal (Pak et al., 1991; M64226), Mus Shab (Pak et al., 1991b; M64228), Aplysia Shaker (Pfaffinger et al., 1991; M95914), Aplysia Shab (Quattrocki et al., 1994; S68356).

in their sensitivity to block by externally applied TF.A. While $j$ Shakl has an $\mathrm{IC}_{50}$ of $20 \mathrm{~mm}$ for external TEA, jShak 2 has an $\mathrm{IC}_{50}$ of approximately $1 \mathrm{~mm}$. This difference is most likely explained by the presence of phenylalanine at position 370 in the pore region of $j S h a k 2$ as opposed to the histidine found in the equivalent position in $j$ Shakl. It has previously been reported that the presence of an aromatic amino acid at this position confers high external TEA sensitivity as seen for $j S h a k 2$, whereas other amino acids result in lowering or abolishing sensitivity to external TEA (Heginbotham and MacKinnon, 1992).

\section{Discussion}

Sequence conservation

Phylogenetic sequence analysis clearly places the jellyfish $\mathrm{K}^{+}$ channels $j S h a k l$ and $j S h a k 2$ within the Shaker gene subfamily of $\mathrm{Vg} \mathrm{K}^{+}$channels. Thus, the Shaker gene subfamily must have diverged from ancestral $\mathrm{Vg} \mathrm{K}^{+}$channels prior to the evolutionary split between diploblasts and triploblasts. It is therefore likely that Shaker $\mathrm{K}^{+}$channels were already playing significant roles in the electrical activity of the earliest metazoan nervous sys-



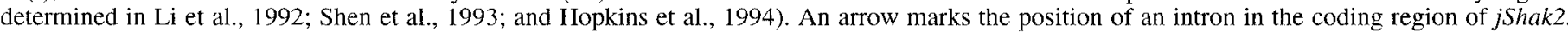
The Genbank accession numbers of the jShakl and jShak2 sequences are U32922 and U32923, respectively. 
$A$



jShak1

Figure 3. Families of outward currents recorded from Xenopus oocytes injected with cRNAs from jShakl $(A)$, jShak2 (B), Drosophila Shaker $B(C)$, and Drosophila Shaker $H 37(D) ; 200$ msec test pulses were applied from $-40 \mathrm{mV}$ to $+60 \mathrm{mV}$ in $20 \mathrm{mV}$ increments for $j S h a k 1$ and $j S h a k 2$, or from

$-60 \mathrm{mV}$ to $+60 \mathrm{mV}$ in $20 \mathrm{mV}$ increments for Shaker B and Shaker H37. Holding potentials were $-90 \mathrm{mV}$ and each pulse was preceded by a $6 \mathrm{sec}$ prepulse to $-130 \mathrm{mV}$ to allow for complete recovery from inactivation between pulses. Current amplitude calibration bars are shown for each set of traces, and a time calibration bar is also provided. Currents were leak subtracted, and capacitative transient currents were clipped.
C

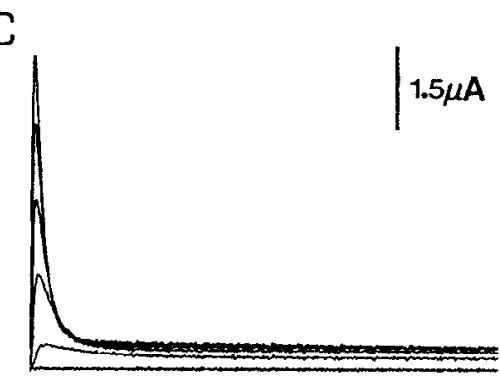

Shaker B
$\mathrm{B}$

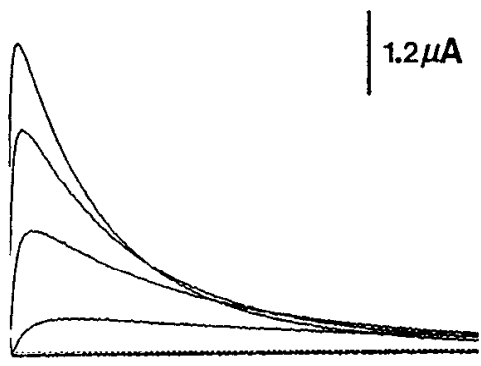

jShak2

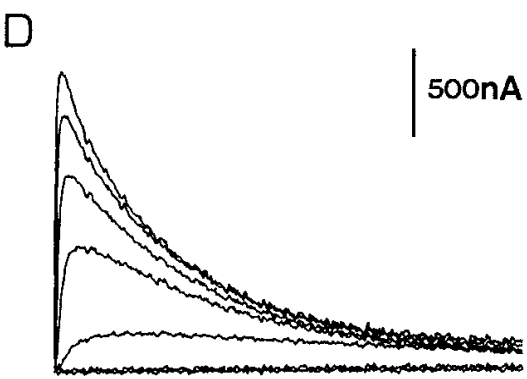

Shaker $\mathrm{H} 37$ tems. This suggests that the establishment of a specialized set of $\mathrm{Vg}$ ion channels to control electrical signaling was one of the early molecular innovations in metazoan cvolution. Additional support for this idea comes from recently obtained evidence that two jellyfish Shal homologs, a putative Shaw homolog, and a third Shaker-related gene may exist in Polyorchis penicillatus
(Jegla and Salkoff, unpublished observations). Other classes of $\mathrm{Vg}$ ion channels also appear to have early origins in metazoans since a scyphozoan jellyfish $\mathrm{Na}^{+}$channel which is homologous to triploblastic $\mathrm{Vg} \mathrm{Na}^{+}$channels has been described (Anderson et al., 1993).

In other experiments to explore the evolutionary origins of

Table 2. Summary of the biophysical and pharmacological properties of the jellyfish $\mathrm{K}^{+}$channels $j$ ShakI and $j S h a k 2$ compared to selected triploblastic Shakers

\begin{tabular}{|c|c|c|c|c|c|}
\hline & jShakI & jShak2 & $K v 1.2$ & Shaker B & Shaker H37 \\
\hline \multicolumn{6}{|l|}{ Activation } \\
\hline$V_{50}(\mathrm{mV})$ & $20.2 \pm 0.3 \quad(n=17)$ & $22.2 \pm 0.2 \quad(n=14)$ & $-15.2 \pm 0.5 \quad(n=6)$ & & $-19.6 \pm 0.4 \quad(n=6)$ \\
\hline Slope $(\mathrm{mV} / e)$ & $12.3 \pm 0.3 \quad(n=17)$ & $11.4 \pm 0.2 \quad(n=14)$ & $8.4 \pm 0.4 \quad(n=6)$ & & $8.3 \pm 0.3 \quad(n=6)$ \\
\hline Limiting slope & $3.51 \pm 0.04(n=5)$ & $4.04 \pm 0.11(n=11)$ & $5.84 \pm 0.35(n=6)$ & & $5.37 \pm 0.19(n=4)$ \\
\hline \multicolumn{6}{|l|}{ Inactivation } \\
\hline$V_{50}(\mathrm{mV})$ & $-20.6 \pm 0.2 \quad(n=9)$ & $-18.9 \pm 0.1 \quad(n=19)$ & & $-44.0 \pm 0.2(n=7)$ & $-43.5 \pm 0.1 \quad(n=6)$ \\
\hline Slope $(\mathrm{mV} / e)$ & $6.2 \pm 0.1 \quad(n=9)$ & $5.2+0.1 \quad(n=19)$ & & $3.9+0.2(n=7)$ & $2.8+0.1 \quad(n=6)$ \\
\hline Tau (msec) & $8.9 \pm 0.2 \quad(n=9)$ & $35.1 \pm 1.4 \quad(n=13)$ & & $3.5 \pm 0.1(n=8)$ & $41.5 \pm 1.6 \quad(n=6)$ \\
\hline $\operatorname{Tau}_{\mathrm{r}-\mathrm{f}}(\mathrm{msec})$ & $24.4 \pm 2.6 \quad(n=5)$ & $245 \pm 7.7 \quad(n=7)$ & & $42.6 \pm 2.0(n=8)$ & \\
\hline $\operatorname{Tau}_{\mathrm{r}-\mathrm{s}}(\mathrm{msec})$ & $855 \pm 56$ & $2075 \pm 60$ & & & $1047 \pm 81 \quad(n=2)$ \\
\hline$\% \mathrm{Tau}_{\mathrm{r}-\mathrm{f}}$ & $43.4 \pm 4.5$ & $26.2 \pm 1.6$ & & & \\
\hline \multicolumn{6}{|l|}{ Pharmacology } \\
\hline TEA IC I $_{50}(\mathrm{mM})$ & $20.0 \pm 2.5 \quad(n=4)$ & $1.2 \pm 0.1 \quad(n=8)$ & & $17.0 \pm 3.4(n=3)$ & \\
\hline 4-AP $\mathrm{IC}_{s v}(\mathrm{mM})$ & $0.5 \pm 0.2 \quad(n=4)$ & $(n=4)$ & & $1.5 \pm 0.6(n=1)$ & \\
\hline
\end{tabular}

Biophysical and pharmacological properties of jShakl and jShak2 are compared to those of two Drosophila Shaker splice variants ( $B$ and H37) and the Mus Shaker homolog $K v 1.2$. The $V_{30}$ and slope (in mV/e-fold change in conductance) of activation and inactivation are derived from the Boltzmann fits of the $\mathrm{gV}$ and steady state inactivation data shown in Figure 7, $A$ and $C$, respectively. The limiting slopes of activation were derived from the linear regression fits to the semilogarithmic plots of $\mathrm{gV}$ curves shown in Figure $7 B$. Tau is the time constant of inactivation and values were determined for the major component of inactivation at $+60 \mathrm{mV}$ $\mathrm{Tau}_{\mathrm{r} f}$ and tau $\mathrm{r}$, are the time constants of the fast and slow components of recovery from inactivation at $-100 \mathrm{mV}$. The percentage of the tntal current that recovers with a time constant of tau ${ }_{r-1}$ is also given. $\mathrm{IC}_{50}$ values for external tetraethylammonium (TEA) and 4-aminopyridine (4-AP) represent the concentration at which the current is reduced to one-half the amplitude of the current in the absence of TEA or 4-AP. Values are \pm SE; sample sizes are given in parentheses. 
A



B

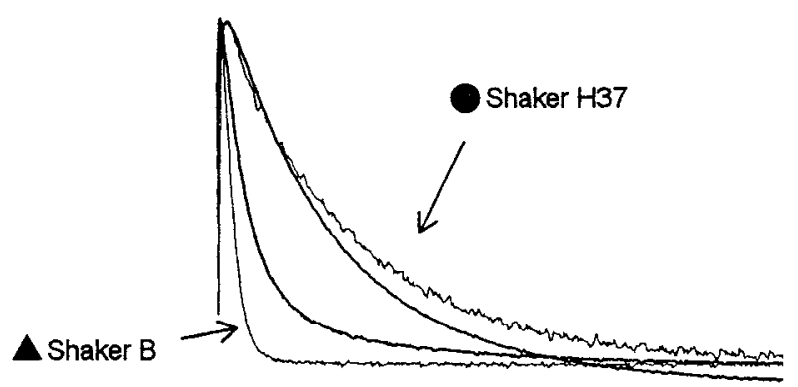

C

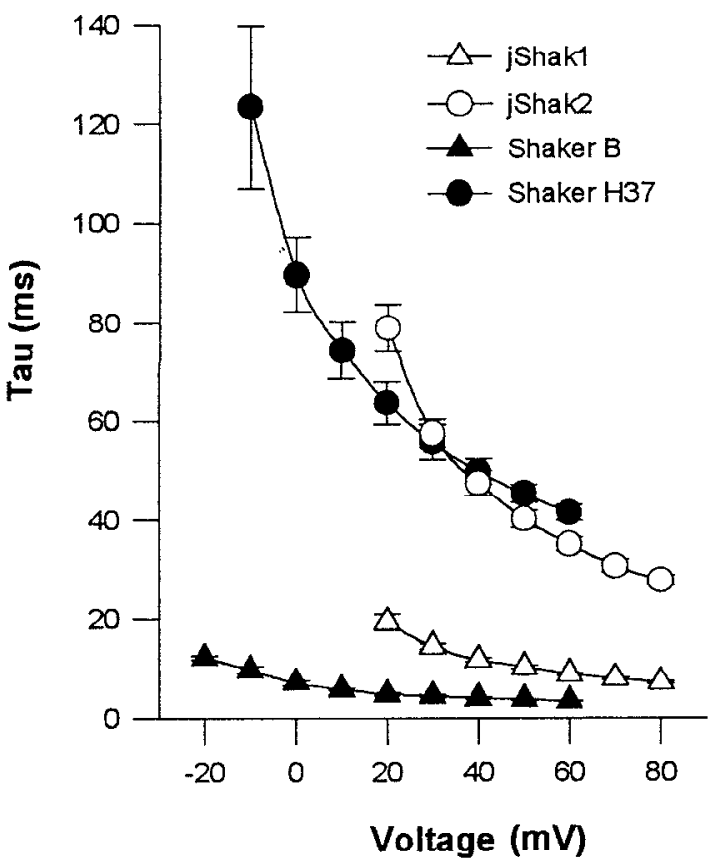

Figure 4. JShakl and jShak2 have distinct inactivation rates. A, Differences in the inactivation rates of the $j S h a k l$ and $j S h a k 2$ currents are illustrated by superimposing current traces from each; currents were elicited by $200 \mathrm{msec}$ steps to $+60 \mathrm{mV}$ and normalized to the same peak amplitude. A time calibration bar is provided. $B$, Similar current traces from the Drosophila Shaker splice variants $B$ and $H 37$ (thin lines) have been added to the $j$ ShakI and jShak 2 current traces (thick lines) shown in $A . C$, Plots of the major time constant of inactivation (tau) versus voltage are shown for $j$ Shak1 $(n=9)$, jShak2 $(n=13)$, Shaker $B(n$ $=8)$, and Shaker H37 $(n=6)$. Error bars show the SE of the data points.
A

$\begin{array}{llr}\text { jShak1 } & \text { MMFVAT } & \text { NRRKKE } \\ \text { jShak2 } & \text { MLPVLT } & \text { QSNRTTSE } \\ \text { Shaker B } & \text { MAAVAGLYGLGEDRQHRKKQ }\end{array}$

B

jShak1T

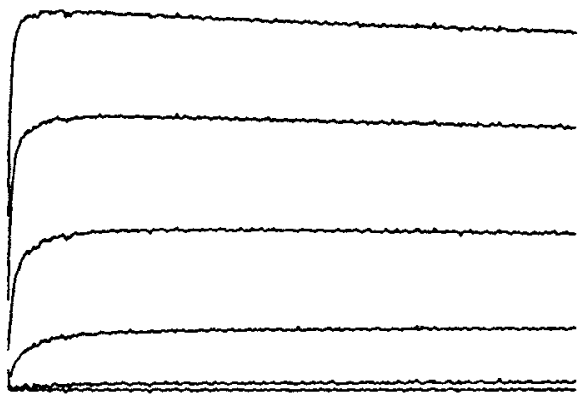

$40 \mathrm{~ms}$

C

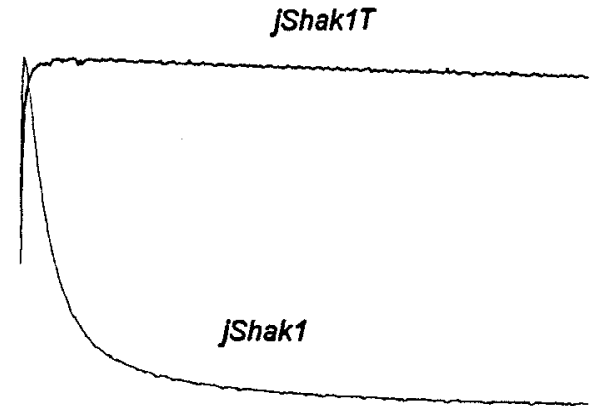

Figure 5. Rapid inactivation of jShakl occurs by a conserved N-terminal mechanism. A, An alignment of the first 12 amino acids of $j S h a k l$ with the N-terminal of Drosophila Shaker $B$ and jShak 2 is shown. White type on black indicates amino acid conservation. B. Outward currents recorded from an oocyte injected with cRNA from a truncated jShakl construct, $j S h a k 1 T$, in response to $200 \mathrm{msec}$ depolarizations from -40 $\mathrm{mV}$ to $+60 \mathrm{mV}$ in $20 \mathrm{mV}$ increments from a holding potential of -90 $\mathrm{mV}$ (peak current at $+60 \mathrm{mV}$ is $3.4 \mu \mathrm{A}$ ). Currents were leak subtracted and capacitative transient currents were clipped. JShak $1 T$ was constructed by removing the first 23 amino acids of jShak1 (see Materials and Methods) $C, 200 \mathrm{msec}$ current traces elicited by depolarization to +60 $\mathrm{mV}$ and normalized to the same peak amplitude are shown for jShakI and $j$ ShaklT. The time calibration bar is for both $B$ and $C$.

voltage-gated $\mathrm{K}^{\prime}$ channels, an identical PCR screening method to that used here failed to reveal close homologs of the Shakerlike $\mathrm{Vg} \mathrm{K}{ }^{+}$channels in the electrically excitable ciliate protozoan Paramecium tetraurelia. Instead, that screen revealed a large family of novel $\mathrm{K}^{+}$channel genes in Paramecium that has only a very ancient relationship to Shaker-like channels (Jegla and Salkoff, 1995). Thus, it may be that the establishment of Shaker-like $\mathrm{K}^{+}$channels as a distinct subclass of $\mathrm{Vg}$ channels is tied to the emergence of metazoans or their direct ancestors, 
A

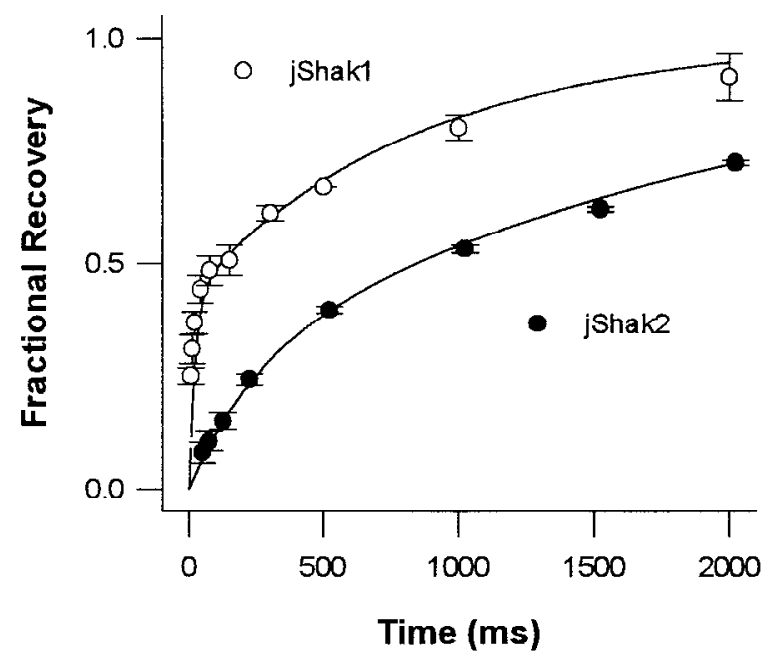

C

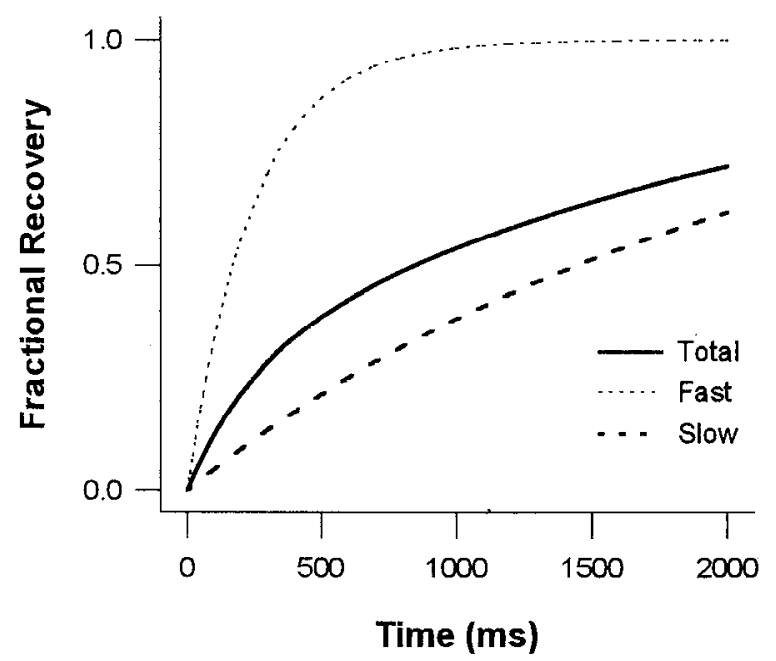

B

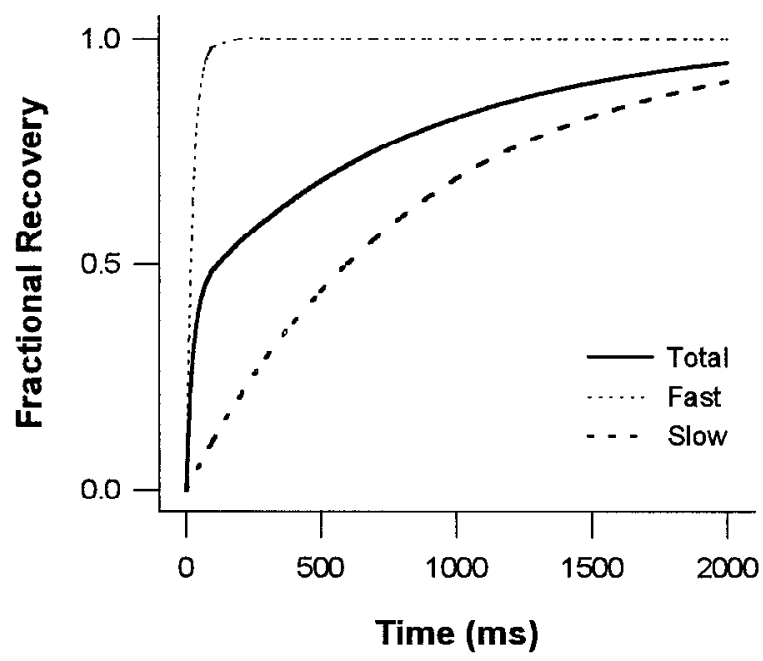

D

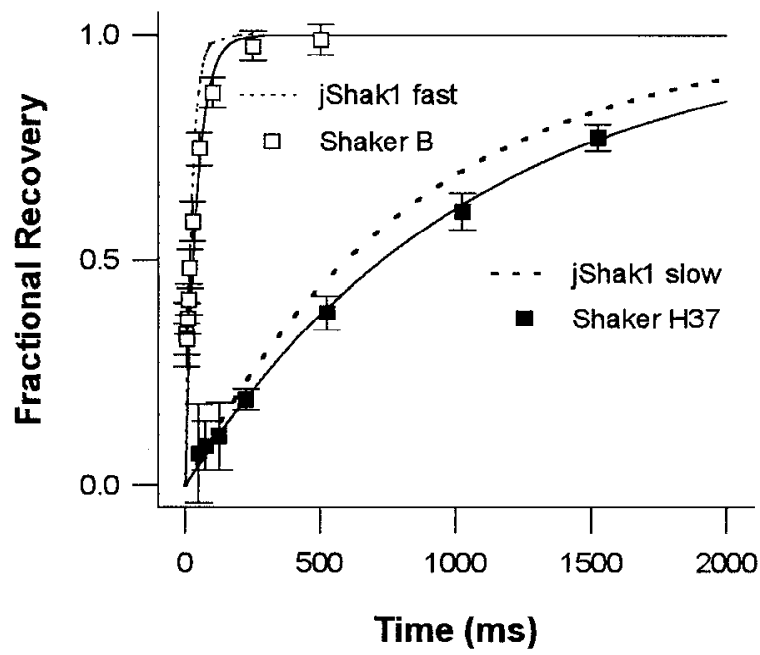

Figure 6. Recovery from inactivation. Curves fitting recovery from inactivation data for jShakl and $j S h a k 2$ at $-100 \mathrm{mV}$ are shown $(A)$. Error bars show the SE of the data points. All recovery rates were determined in CQUANT using double pulse protocols in which two 200 msec pulses to $+10 \mathrm{mV}$ were separated by a pulse to $-100 \mathrm{mV}$ of increasing duration. Holding potentials werc $-100 \mathrm{mV}$ and pulse scrics werc scparatcd by $6 \mathrm{sec}$ intervals at $-130 \mathrm{mV}$ to ensure complete recovery from inactivation. Curves were generated using the equation $I_{t}=\{a \cdot(1-\exp (-t / \operatorname{tau} 1))\}$ $+\{b \cdot(1-\exp (-t / \operatorname{tau} 2))\}$ where $I_{t}$ is the current amplitude measured in the second $+40 \mathrm{mV}$ pulse divided by the current amplitude measure in the first pulse where $t$ is the length of the recovery step at $-100 \mathrm{mV}$, and $a$ and $b$ are the fractions of the total current recovering exponentially with time constants of tau 1 and tau2, respectively. The values of $a, b$, tau1, and tau 2 are shown in Table 2 . Plots of the total recovery rate and the separated fast and slow components of recovery are individually shown for $j$ Shak $I(B)$ and $j S h a k 2(C)$. Curves for each individual exponential component of recovery were normalized to the same amplitude as the total recovery, and were generated using the equation $I_{t}=1-\exp (-t /$ tau $)$, where tau is the time constant reflecting the single rate of recovery. The fast and slow components of the recovery rate of $j S h a k I$ are shown with plots of the recovery rates of Drosophila Shaker B and Shaker $H 37(D)$. The Drosophila Shaker curves were generated using the equation for a single exponential component of recovery.

and possibly to the earliest use of electrical signals for intercellular communication.

Despite our strong evidence that $j$ Shak 1 and $j$ Shak 2 belong in the Shaker gene subfamily, they share substantially less amino acid identity to each other and to previously cloned triploblastic Shaker homologs (around 50\%) than the triploblastic Shakers share with each other (around 70\%) in the core regions of the channels. This divergence may reflect a very ancient split but has not led to large functional differences: the jShak1 and jShak2 currents are surprisingly similar to their Drosophila and Aplysia counterparts, especially with regard to their rapid activation and inactivation (Fig. 3). Thus much of this additional divergence appears neutral with respect to the functional properties that we have measured.

The lower level of conservation between jShak 1 and jShak 2 relative to that shared among triploblastic Shaker channels suggests that these two genes may have been diverging for a much longer time than their triploblastic homologs. If these two lineages split very early in diploblast evolution, homologs of each might be expected to be found in other hydrozoans, if not in all 
A

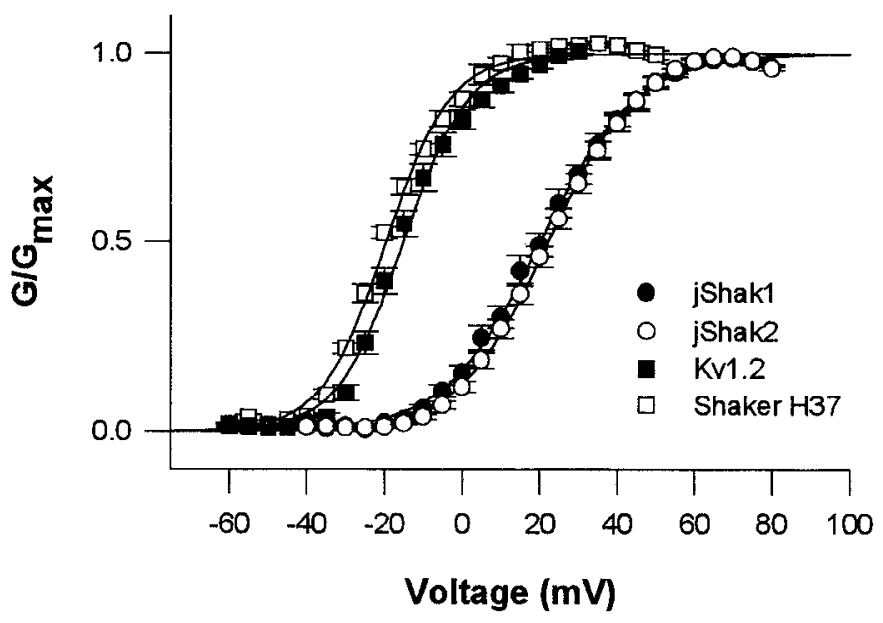

B

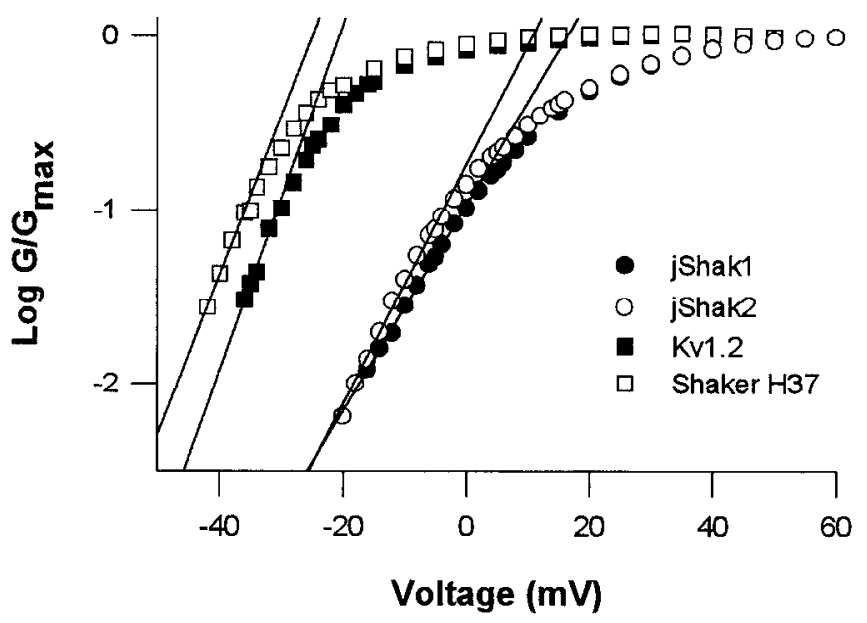

C



Figure 7. Voltage dependence of activation and inactivation. A, Conductance versus voltage curves $(\mathrm{gV})$ are shown for $j \operatorname{Shakl}(n=16)$, cnidarians, much like homologs of specific Shaker genes $(K v 1.1$, $K v 1.2$, etc.) are found throughout the vertebrate classes (Chandy and Gutman, in press).

\section{Functional properties}

'I'he depolarizing shift in the $\mathrm{gV}$ and ssi curves of the jShakI and $j S h a k 2$ currents when compared to typical triploblastic Shaker currents is consistent with observations that several A-type $\mathrm{K}^{+}$currents recorded from cnidarian cells, including those of Polyorchis, show a positive shift in voltage dependence (Anderson and McKay, 1987; Dunlap et al., 1987; Holman and Anderson, 1991; Przysiezniak and Spencer, 1994). A similar positive shift has been described for a jellyfish $\mathrm{Na}^{+}$current (Anderson, 1987) and a calcium current from Polyorchis (Przysiezniak and Spencer, 1992). Whether a reduced voltage sensitivity (with respect to triploblastic Shaker currents) is also a general property of these jellyfish A-type currents, as it is for jShakl and jShak2, is not clear. However, an A-type current in Polyorchis motor neurons does appear to have a reduced voltage sensitivity (Przysiezniak and Spencer, 1994).

Shaker channel homologs produce a more variable set of currents than other types of $\mathrm{Vg} \mathrm{K}^{+}$channel such as Shal or Shab (Salkoff et al., 1992), particularly with respect to rates of inactivation and recovery from inactivation. The differences seen between the jShakl and $j S h a k 2$ currents in both their rates of inactivation and recovery from inactivation parallel those seen in Drosophila Shaker currents. Different splice variants of Drosophila Shaker vary 10 -fold in inactivation rates from Shaker $B$ to Shaker H37. Recovery rate time constants of Drosophila Shaker currents fall into two groups: rapid, like Shaker $B$ (40 msec at $-100 \mathrm{mV}$ ) and slow, like Shaker 1137 or Shakers $A$ and $C$, which take several seconds to recover at $-140 \mathrm{mV}$ (Timpe et al., 1988b). The jShakl current is most similar to Shaker $B$ as it has rapid $\mathrm{N}$-type inactivation and a rapid component to

$\leftarrow$

jShak2 $(n=14)$, Drosophila Shaker H37 $(n=6)$, and mouse Kv1.2 $(n$ $=6)$. Error bars show the SE of the data points and solid curves represent Boltzmann fits of the data $\left(G / G_{\max }=1 /\left(1+\exp \left(-\left(V-V_{50}\right) / a\right)\right.\right.$, where $G$ is the conductance at voltage $V, G_{\text {Irax }}$ is the maximal conductance, $V_{50}$ is the voltage at which $G=0.5 \cdot G_{\max }$, and $a$ is the slope factor. Conductances were determined by correcting peak current for driving force (reversal potential was assumed to be $-90 \mathrm{mV}$ in the ND96 recording solution). Test pulse durations were $100 \mathrm{msec}$ for $j S h a k l, 200$ msec for jShak2 and Shaker H37, and $400 \mathrm{msec}$ for $K v 1.2$. Holding potentials and prepulses were the same as described in Figure 3. B, Semilogarithmic plots of $\mathrm{gV}$ curves obtained in the same manner as in $A$, but with additional data points for voltages at low $g$ values ( $j S h a k l$, $n=5 ;$ Shak $2, n=11$; Shaker H37, $n=4 ; K v I .2, n=6$ ). Lines represent linear regression fits to the data points below $10 \% g_{\max }$, and represent the limiting slope of voltage dependence. The slopes of these lines were directly used to obtain lower limit estimates of the total gating valence $z$ (Table 2) from the equation $z=R T / F \cdot \ln ((G / G \max ) / V$ where $R$ is the gas constant, $T$ is the absolute temperature, $F$ is Faraday's constant, and $\ln ((G / G \max ) / V)$ is the slope of the linear regression fit. $C$, Steady state inactivation curves are shown for jShakl $(n=9), j S h a k 2$ $(n-19)$, and the Drosophila Shaker $B(n=7)$ and Shaker $H 37(n=$ 6) splice variants. Currents were obtained by measuring the peak current during test pulses to $+40 \mathrm{mV}$ preceded by $5 \mathrm{sec}$ prepulses to the voltage showil on the $x$-dxis. Holding potentials were $-90 \mathrm{mV}$ and 6 sec steps to $-130 \mathrm{mV}$ were used between test pulses to provide complete recovery from inactivation. Error bars show the SE of the data points, and the curves represent best fits of the data to the Boltzmann function $I / I_{\max }$ $=1 /\left(1+\exp \left(\left(V-V_{50}\right) / a\right)\right.$, where $I$ is the peak current measured during the test pulse after a prepulse to voltage $V, I_{\max }$ is the maximal current measured, $V_{50}$ is the prepulse voltage at which $I=0.5 \cdot I_{\max }$, and $a$ is the slope factor. 
recovery. The $j S h a k 2$ current, on the other hand, has a slower inactivation rate (like Drosophila Shaker H37 or Aplysia Shaker) and has slow recovery from inactivation (like Drosophila Shakers $H 37, A$ and $C$ ). Shaker currents in mammals are even more variable, ranging from rapid inactivation and slow recovery in Kv1.4 (Stuhmer et al., 1989; Ramaswami et al., 1990) to no inactivation in several mammalian Shaker homologs (Christie et al., 1989; Stuhmer et al., 1989; Grissmer et al., 1990; Swanson et al., 1990). Auxiliary subunits appear to further increase the diversity of inactivation properties in mammalian Shakers (Rettig et al., 1994). Thus, a diversity of Shaker current types appears to have been conserved between diploblasts and triploblasts.

It would appear that nervous systems have used a variety of functionally distinct Shaker currents virtually since their inception, and therefore all or most metazoans require some method of producing Shaker current diversity. In our diploblast representative Polyorchis, Shaker diversity is, at least in part, produced by multiple genes, jShakl and jShak2. As in mammals, alternative splicing is probably not very important in varying the functional properties of these genes because the coding region $j$ Shakl is intronless and the coding region $j S h a k 2$ contains only one intron in the C-terminal cytoplasmic domain. In mammals, as many as eight Shaker homologs exist, but most appear to contain intronless coding regions (Chandy et al., 1990; Douglass et al., 1990; Swanson et al., 1990; Chandy and Gutman, in press), so that alternative splicing probably does not contribute appreciably to Shaker current diversity. In Drosophila, only one Shaker gene appears to exist (Salkoff et al., 1992), but extensive alternative splicing leads to a wide range of functional properties (Jan and Jan, 1990).

The selective pressure to provide a variety of Shaker currents is thus wide-sprcad among metazoan phyla. The reason for this Shaker current diversity is unknown, but may reflect the adaptability of the rapidly activating Shaker current to a variety of roles. For instance, Shaker currents are even found in nonexcitable cells such as T-lymphocytes (Grissmer et al., 1990). Future examinations of more primitive metazoans such as sponges (which have non-neuronal conducting systems; Mackie et al., 1983) and of protozoans presumed to have close evolutionary ties to metazoans will help to more closely determine the relationship between Shaker-like voltage-gated $\mathrm{K}^{+}$channels and the evolution of the nervous system.

\section{References}

Almers W (1978) Gating currents and charge movements in excitable membranes. Rev Physiol Biochem Pharmacol 82:96-190.

Anderson PAV (1987) Properties and pharmacology of a TTX-insensitive $\mathrm{Na}^{+}$current in neurones of the jellyfish Cyanea capillata. $\mathrm{J}$ Exp Biol 133:231-302.

Anderson PAV, McKay MC (1987) The electrophysiology of cnidocytes. J Exp Biol 133:215-230.

Anderson PAV, Holman MA, Greenberg RM (1993) Deduced amino acid sequence of a putative sodium channel from the scyphozoan jellyfish Cyanea capillata. Proc Natl Acad Sci USA 90:7419-7423.

Armstrong CM (1981) Sodium channels and gating currents. Physiol Rev 61:644-683.

Baker K, Salkoff L (1990) The Drosophila Shaker gene codes for a distinctive $\mathrm{K}^{+}$current in a subset of neurons. Neuron 2:129-140.

Butler A, Wei A, Baker K, Salkoff L (1989) A family of putative potassium channel genes in Drosophila. Science 243:943-947.

Chandy KG, Williams CB, Spencer RH, Aguilar BA, Ghanshani S, Tempel BL, Gutman GA (1990) A family of three mouse potassium channel genes with intronless coding regions. Science 247:973-975.
Chandy KG, Gutman GA. Voltage-gated $\mathrm{K}^{+}$channel genes. In: CRC handbook of receptors and channels (North PA, ed), in press.

Christen R, Ratto A, Baroin A, Perasso R, Grell KG, Adoutte A (1991) An analysis of the origins of metazoans, using comparisons of partial sequences of the 28s RNA reveals an early emergence of triploblasts. EMBO J 10:4999-5003.

Christie MJ, Adelman JP, Douglass J, North RA (1989) Expression of a cloned rat brain potassium channel in Xenopus oocytes. Science 244:221-224.

Covarrubias M, Wei A, Salkoff L (1991) Shaker, Shal, Shab and Shaw express independent $\mathrm{K}^{+}$current systems. Neuron 7:763-773.

Douglass J, Osborne PB, Cai YC, Wilkinson M, Christie MJ, Adelman JP (1990) Characterization of $R G K 5$, a genomic clone encoding a lymphocyte channel. J Immunol 144:4841-4850.

Dunlap K, Takeda P, Brehm P (1987) Activation of a calcium-dependent photoprotein by chemical signaling through gap junctions. Nature 325:60-62.

Gallin WJ (1991) Sequence of an acidic ribosomal protein from the jellyfish Polyorchis penicillatus. Biochem Cell Biol 69:211-215.

Grissmer S, Dethlefs B, Wasmuth JJ, Goldin AL, Gutman GA, Cahalan MD, Chandy KG (1990) Expression and chromosomal localization of a lymphocyte $\mathrm{K}^{+}$channel gene. Proc Natl Acad Sci USA 87:94119415

Hartmann HA, Kirsch GE, Drewe JA, Taglialatela M, Joho RH, Brown AM (1991) Exchange of conduction pathways between two related $\mathrm{K}^{+}$channels. Science 251:942-944.

Heginbotham L, MacKinnon R (1992) The aromatic binding site for tetraethylammonium ion on potassium channels. Neuron 8:483-491.

Hevers W, Hardie RC (1995) Serotonin modulates the voltage dependence of delayed rectifier and Shaker potassium channels in Drosophila photoreceptors. Neuron 14:845-856.

Holman M, Anderson PAV (1991) Voltage-activated ionic currents in myoepithelial cells from the sea anemone Calliactis tricolor. J Exp Biol 161:333-346.

Hopkins WF, Demas V, Tempel BL (1994) Both N- and C-terminal regions contribute to the assembly and functional expression of homo- and heteromultimeric voltage-gated $\mathrm{K}^{+}$channels. J Neurosci 14:1385-1393.

Hoshi T, Zagotta WN, Aldrich RW (1990) Biophysical and molecular mechanisms of Shaker potassium channel inactivation. Science 250: 533-538.

Isacoff E, Papazian D, Timpe L, Jan YN, Jan LY (1990) Molecular studics of voltage-gated potassium channels. Cold Spring Ilarbor Symp Quant Biol 55:9-17.

Jan LY, Jan YN (1990) How might the diversity of potassium channels be generated? Trends Neurosci 13:415-419.

Jegla T, Salkoff L (1994) Molecular evolution of $\mathrm{K}^{+}$channels in primitive eukaryotes. In: Molecular evolution of physiological processes (Fambrough DM, ed), pp 213-222. New York: Rockefeller UP.

Jegla T, Salkoff L (1995) A multigene family of novel $\mathrm{K}^{+}$channels from Paramecium tetraurelia. Recept Channels 3:51-60.

Johansen K, Wei A, Salkoff L, Johansen J (1990) A leech gene sequence homologous to Drosophila and mammalian Shaker $\mathrm{K}^{+}$channels. J Cell Biol 111:60a.

Kamb A, Tseng-Crank J, Tanouye MA (1988) Multiple products of the Drosophila Shaker gene may contribute to potassium channel diversity. Neuron 1:421-430.

Kim E, Day TA, Bennett JL, Pax RA (1995) Cloning, characterization and functional expression of a Shaker-related voltage-gated potassium channel gene from Schistosoma Mansoni (Trematoda: Digenea). Parasitology 110:171-180.

Kozak M (1987) At least six nucleotides preceding the AUG initiator codon enhance translation in mammalian cells. J Mol Biol 196:947950.

Li M, Jan YN, Jan LY (1992) Specification of subunit assembly by the hydrophilic amino-terminal domain of the Shaker potassium channel. Science 257:1225-1230.

Logothetis DE, Shahla M, Satler C, Lindpaintner K, Nadal-Ginard B (1992) Incremental reductions of positive charge within the S4 region of a voltage-gated $\mathrm{K}^{+}$channel result in corresponding decreases in gating charge. Neuron 8:531-540.

Mackie GO, Lawn ID, Pavans de Ceccatty M (1983) Studies on hexactinellid sponges II. Excitability, conduction and coordination of responses in Rhabdocalyptus dawsoni. Philos Trans R Soc Lond [Biol] 301:401-418. 
McKinnon D (1989) Isolation of a cDNA clone coding for a putative second potassium channel indicates the existence of a gene family. $J$ Biol Chem 264:8230-8236.

Meech RW, Mackie GO (1993) Potassium channel family in the giant motor axons of Aglantha digitale. J Neurophysiol 69:894-901.

Morris SC (1993) The fossil record and the early evolution of the Metazoa. Nature 361:219-225.

Pak MD, Baker K, Covarrubias M, Butler A, Ratcliffe A, Salkoff L (1991a) mShal, a subfamily of A-type $\mathrm{K}^{+}$channel cloned from mammalian brain. Proc Natl Acad Sci USA 88:4386-4390.

Pak MD, Covarrubias M, Ratcliffe A, Salkoff L (1991b) A mouse brain homologue of the Drosophila Shab $\mathrm{K}^{+}$channel with conserved delayed rectifier properties. J Neurosci 11:869-880.

Papazian DM, Schwarz TL, Tempel BL, Jan YN, Jan LY (1987) Cloning of genomic and complementary DNA from Shaker, a putative potassium channel gene from Drosophila. Science 237:749-753.

Papazian DM, Timpe LC, Jan YN, Jan LY (1991) Alteration of voltage-dependence of Shaker potassium channel by mutations in the S4 sequence. Nature 349:305-310.

Pfaffinger PJ, Furukawa Y, Zhao B, Dugan D, Kandel ER (1991) Cloning and expression of an Aplysia $\mathrm{K}^{+}$channel and comparison with native Aplysia $\mathrm{K}^{+}$currents. J Neurosci 11:918-927.

Pongs O (1993) Shaker-related $\mathrm{K}^{+}$channels. Sem Neurosci 5:93-100.

Przysiesniak J, Spencer AN (1992) Voltage-activated calcium currents in identified neurons from a hydrozoan jellyfish, Polyorchis penicillatus. J Neurosci 12:2065-2078.

Przysiesniak J, Spencer AN (1994) Voltage-activated potassium currents in isolated motor neurons from the jellyfish Polyorchis penicillatus. J Neurophysiol 72:1010-1019.

Quattrocki EH, Marshal J, Kaczmarek LK (1994) A Shab potassium channel contributes to action potential broadening in peptidergic neurons. Neuron 12(1):73-86.

Ramaswami M, Gautam M, Kamb A, Rudy B, Tanouye M, Mathew MK (1990) Human potassium channel genes: molecular cloning and functional expression. Mol Cell Neurosci 1:214-223.

Rettig J, Heinemann SH, Wunder F, Lorra C, Parcej DN, Dolly JO, Pongs $\mathrm{O}$ (1994) Inactivation properties of voltage-gated $\mathrm{K}^{+}$channels altered by presence of $\beta$-subunit. Nature 369:289-294.

Rudy B (1988) Diversity and ubiquity of $\mathbf{K}^{+}$channels. Neuroscience 25:729-749.

Rudy B, Kentros C, Vega-Saenz de Miera E (1991) Families of potassium channel genes in mammals: toward an understanding of the molecular basis of potassium channel diversity. Mol Cell Neurosci 2:89-102.

Salkoff L, Baker K, Butler A, Covarrubias M, Pak MD, Wei A (1992) An essential set of $\mathrm{K}^{+}$channels conserved in flies, mice and humans. Trends Neurosci 15:161-166.

Shen NV, Chen X, Boyer MM, Pfaffinger PJ (1993) Deletion analysis of $\mathrm{K}^{+}$channel assembly. Neuron 11:67-76.
Strong M, Chandy KG, Gutman GA (1993) Molecular evolution of voltage-sensitive ion channel genes: on the origins of electrical excitability. Mol Biol Evol 10:221-242.

Stuhmer W, Ruppersberg JP, Schroter KH, Sakmann B, Stocker M, Glese KP, Perschke A, Baumann A, Pongs O (1989) Molecular basis of functional diversity of voltage-gated potassium channels in mammalian brain. EMBO J 8:3235-3244.

Swanson RA, Marshall J, Smith JS, Williams JB, Boyle MB, Folander $\mathrm{K}$, Luneau CJ, Antanavage J, Oliva C, Buhrow SA, Bennet C, Stein RB, Kaczmarek LK (1990) Cloning and expression of cDNA and genomic clones encoding three delayed rectifier potassium channels in brain. Neuron 4:929-939.

Swofford DL (1993) Phylogenetic analysis using parsimony. Champaign, IL: Illinois Natural History Survey.

Tempel BL, Jan YN, Jan LY (1988) Cloning of a probable potassium channel gene from mouse brain. Nature 332:837-839.

Timpe LC, Schwarz TL, Tempel BL, Papazian DM, Jan YN, Jan LY (1988a) Expression of functional potassium channels from Shaker cDNA in Xenopus oocytes. Nature 331:143-145.

Timpe LC, Jan YN, Jan LY (1988b) Four CDNA clones from the Shaker locus of Drosophila induce kinetically distinct A-type potassium currents in Xenopus oocytes. Neuron 1:659-667.

Wainright PO, Hinkle G, Sogin ML, Stickel SK (1993) Monophyletic origins of the Metazoa: an evolutionary link with fungi. Science 260: $340-341$.

Wei A, Covarrubias M, Butler A, Baker K, Pak M, Salkoff L (1990) Diverse $\mathrm{K}^{+}$currents expressed by a Drosophila extended gene family which is conserved in mouse. Science 248:599-603.

Wei A, Jegla T, Salkoff L (1991) A C. elegans potassium channel gene with homology to Drosophila Shaw. Soc Neurosci Abstr 17:1281 (s10.10).

Wei A, Solaro C, Lingle C, Salkoff L (1994) Calcium sensitivity of BK-type $\mathbf{K}_{\mathrm{ca}}$ channels determined by a separable domain. Neuron 13 : 671-681.

Wishart DS, Boyko RF, Willard L, Richards FM, Sykes BD (1994) SEQSEE: a comprehensive program suite for protein sequence analysis. Comp Appl Biosci 10:121-132.

Yellen G, Jurman ME, Abramson T, Mackinnon R (1991) Mutations affecting internal TEA blockade identify the probable pore-forming region of a $\mathrm{K}^{+}$channel. Science 251:939-942.

Yool AJ, Schwarz TL (1991) Alteration of ionic selectivity of a $\mathrm{K}^{+}$ channel by mutation of the H5 region. Nature 349:700-704.

Zagotta WN, Hoshi T, Aldrich RW (1990) Restoration of inactivation in mutants of Shaker potassium channels by a peptide derived from ShB. Science 250:568-571.

Zhao B, Rasscndren F, Kaang BK, Furakawa Y, Kubo T, Kandel ER (1994) A new class of noninactivating $\mathrm{K}^{+}$channels from Aplysia capable of contributing to the resting potential and firing pattern of neurons. Neuron 13:1205-1213. 